\title{
Audit Tata Kelola Teknologi Informasi Pada PT. EMD Menggunakan COBIT 4.1 dan BSC
}

\author{
Jordi Tomas ${ }^{1)}$, Johanes F. Andry ${ }^{2)}$ \\ Sistem Informasi, Fakultas Teknologi dan Desain, Universitas Bunda Mulia \\ Jalan Lodan Raya No.2, Jakarta Utara, 14430 \\ 1)Email: jordithomasss@gmail.com \\ 2)Email: jandry@bundamulia.ac.id
}

\begin{abstract}
PT. EMD is a company engaged in the distributor of various kinds of Hardware and Lifestyle products. The company is currently in the stage of implementing an information system audit. Previously, this company had implemented an information system as a strategy to support the achievement of business profits in competing in market share. This study aims to assess the information technology governance that has been implemented by the company, so that the writer can provide recommendations for companies to improve the performance of information technology governance. This research uses descriptive research method because it includes data, analysis and interpretation. This research is structured as an inductive research that searches and collects existing data in the field with the aim to measure the level of maturity and recommendation improvement on information technology governance.
\end{abstract}

Keywords: audit, Balance Scorecard, COBIT 4.1, governance, maturity level

\begin{abstract}
Abstrak: PT. EMD merupakan perusahaan yang bergerak pada bidang Distributor berbagai macam produk Hardware dan Lifestyle. Perusahaan tersebut pada saat ini, sedang dalam tahap untuk penerapan audit sistem informasi. Sebelumnya, perusahaan ini telah menerapkan sistem informasi sebagai salah satu strategi untuk mendukung tercapainya keuntungan bisnis dalam bersaing di pangsa pasar. Penelitian ini bertujuan untuk melakukan penilaian terhadap tata kelola teknologi informasi yang sudah diterapkan perusahaan, sehingga penulis dapat memberikan rekomendasi bagi perusahaan untuk memperbaiki dan meningkatkan kinerja tata kelola teknologi informasi. Penelitian ini menggunakan metode penelitian deskriptifkarena meliputi data, analisis dan interpretasi. Penelitian ini disusun sebagai penelitian induktif yakni mencari dan mengumpulkan data yang ada di lapangan dengan tujuan untuk mengukur tingkat kematangan dan memberi rekomendasi perbaikan pada tata kelola teknologi informasi.
\end{abstract}

Kata kunci: audit, Balance Scorecard, COBIT 4.1, maturity level, tata kelola

\section{PENDAHULUAN}

Teknologi informasi menjadi bagian penting dari organisasi dan pemerintah. Layanan yang disediakan IT memberikan kemampuan bagi mereka untuk memenuhi kebutuhan warga atau pelanggan mereka. IT tidak dapat disangkal menjadi elemen penting yang perlu dikelola dengan hati-hati di antara organisasi bisnis [1]. Semakin meningkatnya teknologi, penetrasi teknologi informasi ke dalam organisasi juga semakin meningkat. Adaptasi teknologi informasi dalam proses organisasi inti menjadi dua hal yang tak terpisahkan dan saling terkait dalam melakukan aktivitas perusahaan seharihari, salah satunya ialah dalam proses pengambilan keputusan. Untuk mengolah informasi yang baik, maka seharusnyadibutuhkanlah audit tata kelola teknologi informasi [2].

Tata kelola teknologi informasi menyediakan sebuah struktur yang berguna untuk menghubungkan IT resources, IT process, dan informasi yang dibutuhkan baik bagi strategi dan tujuan dari sebuah perusahaan atau organisasi yang menerapkannya [3]. Banyak organisasi membuat investasi besar dalam IT untuk mengamankan atau mempertahankan keunggulan kompetitif [4].

PT E Media Devices (EMD) merupakan perusahaan yang bergerak di bidang Distributor Hardware dan Lifestyle. Perusahaan ini terus mengalami peningkatan baik keuntungan atau profit dan juga internal prosesnya. Perusahaan ini juga telah menyadari bahwa era digital terus menerus 
meningkat, sehingga keberadaan tata kelola teknologi informasi sangatlah diperlukan. Namun, harus disadari bahwa teknologi informasi ini juga harus ditinjau ulang untuk mengetahui seberapa jauh sistem telah memenuhi kebutuhan. Oleh karena itu, perlu diterapkannya sebuah audit sistem informasi [5].

Gondodiyoto (2007) menjelaskan bahwa pada hakekatnya, audit sistem informasi sebagai audit tersendiri dan bukan merupakan bagian dari audit laporan keuangan, perlu dilakukan untuk memcriksa tingkat kematangan atau kesiapan suatu organisasi dalam melakukan pengelolaan teknologi informasi (IT Governance). Tingkat kesiapan (level of maturity) dapat dilihat dari tata kelola informasi, tingkat kepedulian seluruh stakeholders tentang posisi sekarang dan arah yang diinginkan di masa yang akan datang. Sehingga perencanaan teknologi informasi hendaknya dilakukan tidak dengan asal- asalan. Oleh karenanya, audit sistem informasi (berbasis teknologi informasi) ini mencakup 2 hal, yaitu: 1) Audit sistem informasi atau yang dilaksanakan dalam rangka audit laporan keuangan general financial audit. adalah pemeriksaan terhadap aspek aspck TI pada sistem informasi akuntansi. Panduan yang digunakan adalah Standard Profesional Akuntan Publik (SPAP). Test of control dilakukan terhadap prograprogram komputer dan substantive test dengan pemeriksaan terhadap data file database perusahaan. Audit objectives-nya ialah kesesuaian dengan standard akuntansi keuangan dan tidak adanya salah saji yang material pada laporan keuangan. Sedangkan referensi model sistem pengendalian internal lazimnya adalah Committee of Sponsoring Organization (COSO); dan 2) Audit sistem informasi yang dilakukan dalam kaitannya dengan IT Governance, adalah audit operasional terhadap manajemen/ pengelolaan sumber daya informasi atau audit terhadap kehandalan sistem informasi berbasis TI mengenai aspek- aspek: efektivitas, efisiensi, ekonomis tidaknya unit fungsional sistem informasi, data integrity, safeguarding asses, reliability, confidenciality, availability dan security. Panduan yang digunakan adalah standard atestasi. Sedangkan model referensi sistem pengendalian internal lazimnya ialah Control Objective for Information and related Technology (COBIT). Berbeda dengan general audit yang bersifat mandatory, audit TI bersifat memberikan keyakinan kepada top management apakah pengelolaan sistem informasi di perusahaan sudah on the right track [6].

Sistem informasi audit membutuhkan standar. Standar yang digunakan dalam penelitian ini adalah COBIT 4.1. Tujuan Control Objectives for
Information and Related Technology (COBIT) adalah sebagai standar dalam tata kelola TI untuk membantu perusahaan dalam mengendalikan kebutuhan bisnis dalam perusahaan, di mana kebutuhan bisnis termasuk kegiatan TI dan menekankan kegiatan yang harus dicapai dan dikendalikan secara efektif [7,8]. COBIT 4.1 memiliki 4 domain, yaitu: (1) Plan and Organize (PO) yang berfokus pada proses perencanaan dan menyelaraskan strategi teknologi informasi dengan strategi perusahaan; (2) Acquire and Implement (AI) dengan fokus dalam penerapan solusi teknologi informasi dan integrasinya dalam proses bisnis organisasi untuk mewujudkan teknologi informasi (3) Deliver and Support (DS) dengan fokus pemenuhan layanan pengolahan data yang sedang berlangsung; dan (4) Monitoring and Evaluating (ME) yang berfokus pada pengawasan internal dan eksternal kontrol dan jaminan independen dari proses pemeriksaan yang dilakukan.

Agar berhasil dalam lingkungan yang kompetitif, organisasi harus mengejar dan melaksanakan strategi yang konsisten dengan misi mereka. Manajemen perlu menyelaraskan tujuan dan sasarannya dengan tujuan organisasi untuk melaksanakan strategi secara efektif. Dengan keselarasan ini, manajer termotivasi untuk mencapai tingkat kinerja individu yang lebih tinggi [9]. Tingkat kinerja dalam suatu perusahaan dapat dinilai menggunakan Balanced Scorecard.

Balance Scorecard (BSC) adalah sistem yang memungkinkan organisasi untuk menerjemahkan visi dan strategi ke dalam tindakan dan Balanced Scorecard adalah alat untuk merumuskan apa yang harus diukur oleh organisasi [10]. Pada awalnya, Balance Scorecard berfokus pada strategi bisnis, tetapi bisa juga diterapkan pada proses yang terjadi di dalam perusahaan, termasuk inovasi [11]. Tujuan dari penelitian ini adalah untuk mempelajari konsep Balanced Scorecard dan perannya adalah kinerja organisasi, serta mengetahui keselarasan IT dengan kinerja perusahaan [12]. Menurut Kaplan dan Norton dalam Gasperz (2005), perspektif BSC yaitu: perspektif keuangan, perspektif pelanggan, perspektif proses internal, perspektif pembelajaran dan pertumbuhan. [13]. Domain yang digunakan dalam penelitian ini adalah ME1, ME4, DS5, DS8, dan ME11. Standar COBIT dipilih karena COBIT memiliki deskripsi paling rinci tentang strategi dan kontrol dalam pengaturan proses teknologi informasi yang mendukung strategi bisnis, di mana kerangka kerja terdiri dari 4 domain. Penelitian ini juga menggunakan standart BSC yang berfokus pada perpektif pelanggan dan proses internal. 
Berdasarkan uraian yang telah dipaparkan oleh penulis pada latar belakang masalah dan agar pembahasan tidak menyimpang dari judul penulisan tesis, maka penulis merumuskan masalah yang akan dibahas dalam penulisan ini sebagai berikut: 1) Bagaimana keselarasan antara TI dengan kinerja perusahaan?; 2) Bagaimana penilaian kinerja perusahaan dalam perspektif Balance Scorecard?; 3) Bagaimana kondisi penerapan tata kelola teknologi informasi pada PT. EMD dengan menggunakan Framework COBIT 4.1 berdasarkan Domain Monitor and Evaluation (ME1, ME4), dan Deliver and Support (DS5, DS8, DS11)?; 4) Bagaimana maturity level dan expected level tata kelola teknologi informasi yang diterapkan PT. EMD pada sub-domain ME1, ME4, DS5, DS8, DS11?; 5) Bagaimana rekomendasi yang tepat untuk meningkatkan tata kelola teknologi informasi pada PT. EMD?

Penelitian ini bertujuan untuk: Mengetahui maturity level dengan expected maturity dan current maturity pada sub-domain ME1, ME4, DS5, DS8, DS11 dan Balanced Scorecard dengan perspektif pelanggan dan proses internal pada PT. EMD; dan Memberikan rekomendasi dan saran untuk perbaikan dan peningkatan tata kelola IT pada PT. EMD.

\section{METODE PENELITIAN}

Metode penelitian merupakan cara yang digunakan peneliti untuk mencapai target atau tujuan. Metode penelitian berhubungan dengan prosedur, alat, dan desain penelitian yang digunakan dalam melaksanakan penelitian. Proses dalam penelitian ini mengarah sesuai dengan alur yang logis. Tujuannya

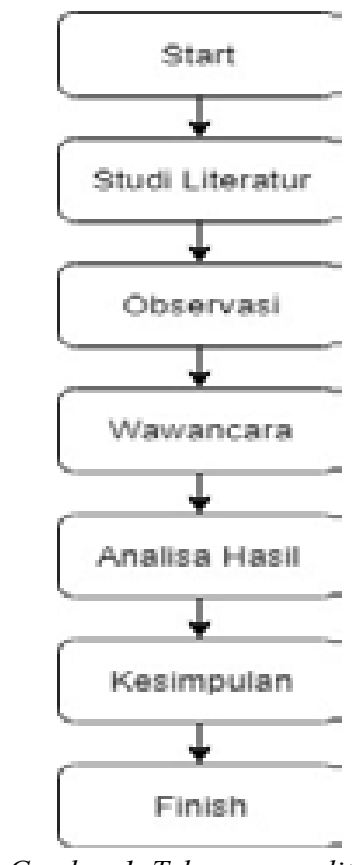

Gambar 1. Tahapan penelitian adalah memberikan petunjuk yang jelas dan sistematis. Tahapan penelitian ini dapat dilihat pada Gambar 1. Tahapan Penelitian.

Pada Gambar 1. Tahap Penelitian di atas, tahap awal penelitian ini adalah studi literature, yaitu penulis mempelajari materi atau tema pembahasan terlebih dahulu, seperti mempelajari COBIT 4.1, Balance Scorecard, serta penelitian - penelitian terdahulu. Tahap yang kedua ialah, melakukan observasi, yaitu penulis terjun ke lapangan secara langsung, dalam kasus ini penulis mengunjungi kantor PT. EMD. Tahap ketiga adalah melakukan wawancara. Penulis mempersiapkan terlebih dahulu pertanyaanpertanyaan yang berhubungan dengan sub-sub domain pada ME1, ME4, DS5, DS8, dan DS11, serta pertanyaan mengenai visi misi perusahaan dan dari sisi IT perusahaan pula, yang berhubungan dengan perspektif pelanggan dan internal proses. Penulis melakukan wawancara dengan CEO dan karyawan IT pada PT. EMD. Setelah melakukan wawancara, penulis menganalisa hasil dari wawancara tersebut dan mengimplementasikannya untuk memperoleh penilaian. Setelah hasil penilaian didapatkan, penulis memberi kesimpulan dan saran untuk perusahaan PT. EMD untuk meningkatkan kinerja pada tata kelola teknologi informasi yang sudah dimiliki.

Penelitian ini menggunakan metode penelitian deskriptif karena meliputi data, analisis dan komunikasi melalui lisan. Penelitian ini disusun sebagai penelitian induktif yakni mencari dan mengumpulkan data yang ada di lapangan dengan tujuan untuk mengukur tingkat kematangan dan rekomendasi pada tata kelola teknologi informasi PT. EMD. Proses bisnis merupakan sebuah kumpulan hubungan pekerjaan yang menghasilkan nilai untuk pelanggan tetapi juga berkontribusi untuk mencapai tujuan. Salah satu proses bisnis pada suatu perusahaan adalah penjualan. Pada PT. EMD, proses penjualan merupakan salah satu bagian yang perlu diberi perhatian khusus, tentu karena penjualan merupakan sumber pendapatan mereka. Sebagai perusahaan distributor, PT. EMD harus selalu menyiapkan stok barang dari para suppliers. Stok barang tersebut akan disimpan di gudang, dan akan diperjualkan melalui agen dan sales PT. EMD. Berikut ini terdapat flowchart proses penjualan pada PT. EMD dapat dilihat pada Gambar 2. Flowchart Penjualan PT. EMD.

Pada Gambar 2. Flowchart Penjualan PT. EMD diatas, perusahaan melakukan pengambilan barang dan mempersiapkan stok gudang terlebih dahulu, kemudian ketika agen atau customer memesan barang, pihak perusahaan (sales) harus check stok 


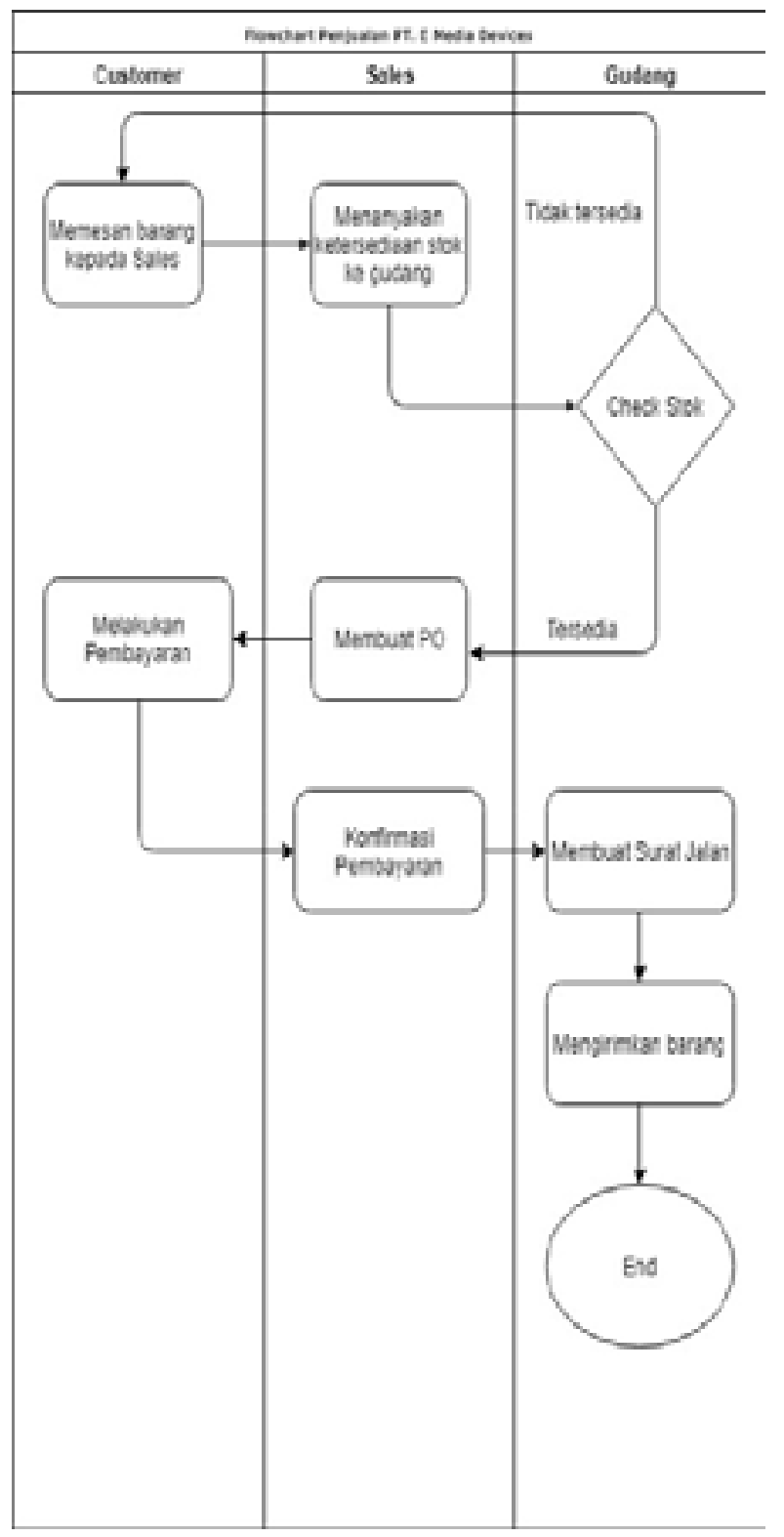

Gambar 2. Flowchart penjualan PT. EMD

ketersediaan barang tersebut terlebih dahulu. Bila stok barang tersedia, maka sales dapat mengkonfirmasi kepada agen atau customer untuk segera dibuatkan PO (Purchase Order), namun bila stok barang kosong, maka PO tidak dapat dibuat. Setelah itu, semua barang pesanan akan segera dikirimkan kepada agen atau customer.

\section{HASIL DAN PEMBAHASAN}

Pada pembahasan ini, peneliti akan menjelaskan mengenai hasil analisis maturity level dan keselarasan IT dengan kinerja perusahaan pada perspektif pelanggan dan proses internal.

\section{ME1 Monitor and Evaluate IT Performance}

Proses ini membahas tentang manajemen kinerja TI yang efektif, memerlukan proses pemantauan (monitoring). Proses ini mencakup penentuan indikator kinerja yang relevan, pelaporan kinerja yang sistematis dan tepat waktu, serta segera bertindak berdasarkan penyimpangan. Pemantauan diperlukan untuk memastikan bahwa apa yang dilakukan atau dikerjakan sesuai dengan kebijakan dan arahan yang ditetapkan. Domain ini terbagi menjadi 6 subdomain, dapat dilihat pada Tabel 1. Hasil Perhitungan Maturity Level ME1.

Tabel 1. Hasil perhitungan maturity level ME1

\begin{tabular}{llc}
\hline Domain & \multicolumn{1}{c}{ Keterangan } & Level \\
\hline ME1.1 & Monitoring Approach & 3 \\
\hline ME1.2 & $\begin{array}{l}\text { Definition and } \\
\text { Collection of } \\
\text { Monitoring Data }\end{array}$ & 2 \\
\hline ME1.3 & Monitoring Method & 2 \\
\hline ME1.4 & $\begin{array}{l}\text { Performance } \\
\text { Assessment }\end{array}$ & 2 \\
\hline ME1.5 & $\begin{array}{l}\text { Board and Executive } \\
\text { Reporting }\end{array}$ & 3 \\
\hline ME1.6 & Remedial Actions & 2 \\
\hline & Rata-rata & 2.3 \\
\hline
\end{tabular}

\section{ME1.1 Monitoring Approach}

Membentuk kerangka pemantauan umum dan pendekatan untuk menentukan ruang lingkup, metodologi dan proses yang harus diikuti untuk mengukur solusi teknologi informasi. Mengintegrasikan kerangka dengan sistem kantor.

\section{ME1.2 Monitoring Approach}

Bekerja dengan bisnis untuk menentukan keseimbangan target dan memastikan target telah disetujui oleh pemangku kepentingan. Menentukan tolok ukur yang dapat digunakan untuk membandingkan sasaran, dan mengidentifikasi data yang tersedia yang dikumpulkan untuk mengukur target. Menetapkan proses untuk mengumpulkan data yang tepat waktu dan akurat untuk melaporkan kemajuan terhadap target.

\section{ME1.3 Monitoring Method}

Memantau kinerja (misalnya, balanced scorecard) yang mencatat target, memberikan ringkasan view kinerja teknologi informasi, dan memasukan kedalam sistem pemantauan perusahaan. 


\section{ME1.4 Performance Assessment}

Secara berkala meninjau kinerja terhadap target, menganalisis penyebab penyimpangan, dan memulai tindakan perbaikan untuk mengatasi penyebab penyimpangan.

\section{ME1.5 Board and Executive Reporting}

Mengembangkan laporan manajemen senior yang berhubungan dengan hasil dukungan teknologi informasi terhadap bisnis, khususnya dalam hal kinerja portofolio perusahaan, program investasi IT, solusi dan layanan kinerja penyampaian program individu. Melaporkan sejauh mana tujuan yang direncanakan telah dicapai, sumber daya yang dianggarkan digunakan, kinerja yang telah ditargetkan terpenuhi. Memberikan laporan dokumentasi kepada manajemen senior, dan mengumpulkan umpan balik dari tinjauan manajemen, serta mengarsipkannya.

\section{ME1.6 Remedial Actions}

Mengidentifikasi dan melakukan tindakan perbaikan berdasarkan pemantauan kinerja, penilaian dan pelaporan. Ini termasuk tindak lanjut dari semua pemantauan, pelaporan dan penilaian melalui: Review, negosiasi dan terbentukanya tanggapan dari manajemen; dan Penugasan tanggung jawab untuk perbaikan.

\section{ME4 Provide IT Governance}

Proses ini membahas mengenai penetapan kerangka kerja tata kelola IT yang efektif, mencakup

Tabel 2. Hasil perhitungan maturity level ME4

\begin{tabular}{llc}
\hline Domain & \multicolumn{1}{c}{ Keterangan } & Level \\
\hline ME4.1 & $\begin{array}{l}\text { Establishment of an IT } \\
\text { Governance } \\
\text { Framework }\end{array}$ & 2 \\
\hline ME4.2 & Strategic Alignment & 3 \\
\hline ME4.3 & Value Delivery & 2 \\
\hline ME4.4 & Resource Management & 2 \\
\hline ME4.5 & Risk Management & 2 \\
\hline ME4.6 & $\begin{array}{l}\text { Performance } \\
\text { Measurement }\end{array}$ & 2 \\
\hline ME4.7 & $\begin{array}{l}\text { Independent } \\
\text { Assurance }\end{array}$ & 2 \\
\hline & Rata-rata & 2.14 \\
\hline
\end{tabular}

penentuan struktur organisasi, proses, kepemimpinan, peran dan tanggung jawab untuk memastikan bahwa investasi IT perusahaan selaras dan disampaikan sesuai dengan strategi dan sasaran perusahaan. Domain ini terbagi menjadi 7 sub-domain yang dapat dilihat pada Tabel 2. Hasil Perhitungan Maturity Level ME4.

\section{ME4.1 Establishment of an IT Governance \\ Framework}

Menentukan, menetapkan dan menyelaraskan kerangka tata kelola teknologi informasi dengan tata kelola perusahaan secara keseluruhan. Mengkonfirmasikan bahwa kerangka tata kelola teknologi informasi memiliki kepatuhan terhadap hukum dan sejalan dengan peraturan, serta menegaskan pelaksaan, strategi dan tujuan dari perusahaan.

\section{ME4.2 Strategic Alignment}

Memastikan pemahaman yang sama antara bisnis dan teknologi informasi mengenai strategi bisnis, memperjelas peran teknologi informasi dalam mendukung bisnis, menuliskannya dalam daftar aturan dan sistem kerja, memastikan kepercayaan antara fungsi teknologi informasi dan bisnis dapat saling mendukung, teknologi informasi dapat memberikan dampak perkembangan dan kemudahan dalam menjalankan bisnis, dan antara manajamen eksekutif dapat memberikan komitmen terhadap pengembangan teknologi informasi.

\section{ME4.3 Value Delivery}

Mengelola investasi teknologi informasi dan aset teknologi informasi lainnya dan memastikan teknologi informasi dapat mendukung strategi perusahaan dan tujuan dengan sangat maksimal, memastikan dengan layanan baru dapat meningkatkan efisiensi dan peningkatan responsivitas untuk permintaan pelanggan, mengelola portfolio dengan benar dan seluruh asset teknologi informasi dikelola dengan benar sehingga dapat mengoptimasi biaya.

\section{ME4.4 Resource Management}

Mengawasi investasi, penggunaan dan alokasi sumber daya teknologi informasi melalui penilaian secara reguler dan memastikan sumber daya yang tepat dan sejalan dengan tujuan strategis saat ini dan masa depan.

\section{ME4.5 Risk Management}

Membuat suatu program atau system komputerisasi yang dapatdigunakan untuk mengelola 
resiko-resiko. System komputerisasi ini, diharapkan dapat mempermudah pengelolaan resiko perusahaan dengan akurasi, kecepatan, dan penyimpanannya. Perawatan fasilitas IT perusahaan juga harus dilakukan secara rutin untuk mencegah atau meminimalkan kemungkinan terjadinya kerusakan.

\section{ME4.6 Performance Measurement}

Progress pencapaian tujuan bisnis dari investasi TI dilaporkan ke pihak management untuk dipantau apabila akan ada tujuan yang tidak tercapai atau tidak sesuai yang diharapkan.

\section{ME4.7 Independent Assurance}

Selalu melakukan evaluasi secara rutin untuk membahas performa IT, mengidentifikasi kekurangannya, serta mencari solusi untuk mengatasi atau memimalisirnya.

\section{DS5 Ensure Systems Security}

Kebutuhan untuk menjaga integritas informasi dan melindungi aset TI membutuhkan proses manajemen keamanan. Proses ini termasuk menetapkan dan mempertahankan peran keamanan dan tanggung jawab TI, kebijakan, standar, dan prosedur. Manajemen keamanan yang efektif harus melindungi semua aset TI. Domain ini terbagi menjadi 11 sub-domain yang dapat dilihat pada Tabel 3. Hasil Perhitungan Maturity Level DS5.

\section{DS5.1 Management of IT Security}

Mengelola keamanan TI di organisasi tertinggi dengan tingkat yang tepat, sehingga pengelolaan tindakan keamanan ini sejalan dengan kebutuhan bisnis.

\section{DS5.2 IT Security Plan}

Menjelaskan bisnis, risiko dan kepatuhan persyaratan menjadi rencana keamanan TI secara keseluruhan, dengan mempertimbangkan TI infrastruktur dan keamanan. Memastikan bahwa rencana diimplementasikan dalam kebijakan dan prosedur keamanan bersama-sama dengan investasi yang tepat dalam layanan, personil, perangkat lunak dan perangkat keras. Berkomunikasi kebijakan keamanan dan prosedur untuk stakeholder dan pengguna.

\section{DS5.3 Identity Management}

Memastikan bahwa semua pengguna (internal, eksternal dan sementara) dan aktivitas mereka pada sistem TI (aplikasi bisnis, IT lingkungan, sistem
Tabel 3. Hasil perhitungan maturity level DS5.

\begin{tabular}{|c|c|c|}
\hline Domain & Keterangan & Level \\
\hline$D S 5.1$ & Management IT security & 2 \\
\hline DS5.2 & IT Security Plan & 2 \\
\hline$D S 5.3$ & Identity Management & 2 \\
\hline$D S 5.4$ & User Account Management & 0 \\
\hline$D S 5.5$ & $\begin{array}{l}\text { Security Testing, } \\
\text { Surveillance and } \\
\text { Monitoring }\end{array}$ & 2 \\
\hline DS5.6 & Security Incident Definition & 2 \\
\hline$D S 5.7$ & $\begin{array}{l}\text { Protection of Security } \\
\text { Technology }\end{array}$ & 2 \\
\hline$D S 5.8$ & $\begin{array}{l}\text { Cryptographic Key } \\
\text { Management }\end{array}$ & 0 \\
\hline$D S 5.9$ & $\begin{array}{l}\text { Malicious Software } \\
\text { Prevention, Detection and } \\
\text { Correction }\end{array}$ & 2 \\
\hline$D S 5.10$ & Network Security & 2 \\
\hline$D S 5.11$ & Exchange of Sensitive Data & 2 \\
\hline & Rata-rata & 1.63 \\
\hline
\end{tabular}

operasi, pengembangan dan pemeliharaan) secara unik diidentifikasi.

\section{DS5.4 User Account Management}

Meminta alamat, membangun, menerbitkan, menangguhkan, memodifikasi dan menutup akun pengguna dan hak pengguna. Menyertakan prosedur persetujuan dan menguraikan data atau sistem pemilik dengan pemberian hak akses, prosedur ini harus berlaku untuk semua pengguna, termasuk administrator (pengguna istimewa) dan pengguna internal dan eksternal, untuk normal dan darurat kasus.

\section{DS5.5 Security Testing, Surveillance and Monitoring}

Tes dan memonitor pelaksanaan keamanan TI secara proaktif. Keamanan IT harus terakreditasi pada waktu yang tepat untuk memastikan bahwa dasar keamanan informasi perusahaan yang disetujui ini dipertahankan. 


\section{DS5.6 Security Incident Definition}

Mendefinisikan dan mengkomunikasikan karakteristik insiden keamanan potensial sehingga mereka dapat diklasifikasikan dengan benar oleh insiden dan masalah manajemen proses.

\section{DS5. 7 Protection of Security Technology}

Membuat teknologi yang berhubungan dengan keamanan tahan terhadap gangguan, dan tidak mengungkapkan dokumentasi keamanan tidak perlu.

\section{DS5.8 Cryptographic Key Management}

Menentukan bahwa kebijakan dan prosedur di tempat untuk mengatur generasi, perubahan, pencabutan, perusakan, distribusi, sertifikasi, penyimpanan, masuk, penggunaan dan pengarsipan kunci kriptografi untuk memastikan perlindungan kunci terhadap modifikasi dan pengungkapan yang tidak sah.

\section{DS5.9 Malicious Software Prevention, Detection and Correction}

Masukan preventif, dan langkah-langkah perbaikan di tempat (Terutama mengupdate patch keamanan dan kontrol virus) di organisasi untuk melindungi sistem informasi dan teknologi dari malware (misalnya, virus, worm, spyware, spam).

\section{DS5.10 Network Security}

Menggunakan teknik dan prosedur keamanan manajemen terkait (Misalnya, firewall, peralatan keamanan, segmentasi jaringan, intrusion detection) untuk mengotorisasi akses dan kontrol informasi mengalir dari dan ke jaringan.

\section{DS5.11 Exchange of Sensitive Data}

Pertukaran data transaksi sensitif harusnya hanya melalui jalur terpercaya atau menengah dengan kontrol untuk menyediakan keaslian konten, bukti pengajuan, bukti penerimaan dan non-repudiation asal.

\section{DS8 Manage Service Desk and Incidents}

Proses ini membahas mengenai respon yang tepat waktu dan efektif terhadap pertanyaan dan masalah pengguna TI, memerlukan meja layanan, dan proses manajemen kejadian yang dirancang dengan baik dan benar. Proses ini mencakup pengaturan fungsi meja layanan dengan registrasi, peningkatan kejadian, analisis trend dan akar penyebab, dan resolusi. Manfaat bisnis mencakup peningkatan produktivitas melalui penyelesaian cepat permintaan pengguna. Selain itu, bisnis dapat mengatasi akar penyebab (seperti pelatihan pengguna yang buruk) melalui pelaporan yang efektif. Domain ini terbagi menjadi 5 sub-domain yang dapat dilihat pada Tabel 4. Hasil Perhitungan Maturity Level DS8.

Tabel 4. Hasil perhitungan maturity level DS8

\begin{tabular}{llc}
\hline Domain & \multicolumn{1}{c}{ Keterangan } & Level \\
\hline DS8.1 & Service Desk & 2 \\
\hline DS8.2 & $\begin{array}{l}\text { Registration of } \\
\text { Customer } \\
\text { Queries }\end{array}$ & 0 \\
\hline DS8.3 & $\begin{array}{l}\text { Incident } \\
\text { Escalation }\end{array}$ & 2 \\
\hline DS8.4 & Incident Closure & 2 \\
\hline DS8.5 & $\begin{array}{l}\text { Reporting and } \\
\text { Trend Analysis }\end{array}$ & 2 \\
\hline & Rata-rata & 1.6 \\
\hline
\end{tabular}

\section{DS8.1 Service Desk}

Membangun fungsi service desk, yang merupakan user interface dengan IT, untuk mendaftar, berkomunikasi, pengiriman dan menganalisa semua panggilan, melaporkan insiden, permintaan layanan dan tuntutan informasi. Harus ada pemantauan dan prosedur eskalasi berdasarkan tingkat disepakati layanan relatif terhadap SLA yang tepat yang memungkinkan klasifikasi dan prioritas dari setiap dilaporkan masalah karena sebuah insiden, permintaan layanan atau permintaan informasi.

\section{DS8.2 Registration of Customer Queries}

Membangun fungsi dan sistem untuk memungkinkan login dan pelacakan panggilan, insiden, permintaan layanan dan kebutuhan informasi. Setiap insiden harus diklasifikasikan menurut prioritas bisnis dan layanan dan dialihkan ke tim manajemen masalah yang tepat. Informasi pelanggan harus disimpan sesuai dengan permintaan mereka.

\section{DS8.3 Incident Escalation}

Menetapkan prosedur layanan meja, sehingga insiden yang tidak dapat diselesaikan dapat secara tepat ditingkatkan sesuai dengan batas-batas yang ditetapkan dalam SLA. Memastikan insiden kepemilikan dan pemantauan siklus dengan service desk untuk user, terlepas mana kelompok IT bekerja pada resolusi kegiatan. 


\section{DS8.4 Incident Closure}

Menetapkan prosedur untuk pemantauan yang tepat waktu terhadap pelanggan. Saat masalah telah diselesaikan, dan memastikan bahwa meja layanan telah mencatat langkah-langkah resolusi, dan pastikan bahwa tindakan yang dilakukan telah disetujui oleh pelanggan. Adanya prosedur dalam pemantauan pelanggan ini dapat menjadi suatu prinsip atau pedoman bagi karyawan perusahaan.

\section{DS8.5 Reporting and Trend Analysis}

Menghasilkan laporan kegiatan layanan meja (service desk) untuk memungkinkan manajemen untuk mengukur kinerja pelayanan dan merespon layanan dan untuk mengidentifikasi tren atau masalah berulang, sehingga layanan dapat terus ditingkatkan. Service desk sebenarnya sangat membantu proses bisnis pada perusahaan atau organisasi.

\section{DS11 Manage Data}

Proses ini membahas mengenai pengelolaan data yang efektif memerlukan identifikasi kebutuhan data. Proses pengelolaan data juga mencakup penetapan prosedur yang efektif untuk mengelola perpustakaan media, backup dan pemulihan data, serta pembuangan media yang tepat. Pengelolaan data yang efektif membantu dalam memastikan kualitas, ketepatan waktu, dan ketersediaan data bisnis. Pengelolaan data merupakan salah satu pekerjaan yang sangat beresiko, karena itu perlu dilakukan dengan teliti. Domain ini terbagi menjadi 6 sub-domain yang dapat dilihat pada Tabel 5. Hasil Perhitungan Maturity Level DS11.

Tabel 5. Hasil perhitungan maturity level DS11.

\begin{tabular}{llc}
\hline Domain & \multicolumn{1}{c}{ Keterangan } & Level \\
\hline DS11.1 & $\begin{array}{l}\text { Business Requirements } \\
\text { for Data Management }\end{array}$ & 2 \\
\hline DS11.2 & $\begin{array}{l}\text { Storage and Retention } \\
\text { Arrangements }\end{array}$ & 2 \\
\hline DS11.3 & $\begin{array}{l}\text { Media Library } \\
\text { Management System }\end{array}$ & 2 \\
\hline DS11.4 & Disposal & 2 \\
\hline DS11.5 & $\begin{array}{l}\text { Backup and } \\
\text { Restoration }\end{array}$ & 3 \\
\hline DS11.6 & $\begin{array}{l}\text { Security Requirements } \\
\text { for Data Management }\end{array}$ & 2 \\
\hline & Rata-rata & 2.17 \\
\hline
\end{tabular}

\section{DS11.1 Business Requirements for Data Management}

Pastikan seluruh output sesuai dengan persyaratan bisnis dan perlu adanya dukungan restart dan kebutuhan pengolahan.

\section{DS11.2 Storage and Retention Arrangements}

Mendefinisikan dan menerapkan prosedur untuk data yang efektif dan efisien penyimpanan, retensi dan pengarsipan untuk memenuhi tujuan usaha, kebijakan keamanan organisasi dan persyaratan peraturan.

\section{DS11.3 Media Library Management System}

Mendefinisikan dan menerapkan prosedur untuk menjaga inventarisasi disimpan dan diarsipkan media untuk memastikan kegunaan dan integritas mereka.

\section{DS11.4 Disposal}

Mendefinisikan dan menerapkan prosedur untuk memastikan bisnis yang persyaratan untuk perlindungan data sensitif dan perangkat lunak bertemu ketika data dan perangkat keras yang dibuang atau dipindahkan.

\section{DS11.5 Backup and Restoration}

Mendefinisikan dan menerapkan prosedur untuk backup dan pemulihan sistem, aplikasi, data dan dokumentasi sesuai dengan kebutuhan bisnis dan rencana kesinambungan.

\section{DS11.6 Security Requirements for Data Management}

Mendefinisikan dan menerapkan kebijakan dan prosedur untuk mengidentifikasi dan menerapkan persyaratan keamanan yang berlaku untuk penerimaan, pengolahan, penyimpanan dan output data untuk memenuhi kebutuhan tujuan bisnis.

Rangkuman Tingkat Kematangan

Hasil perhitungan mendapati rata-rata nilai domain tata kelola teknologi informasi pada Perusahaan E Media Devices sebesar 1.97. Dari penilaian tersebut dapat disimpulkan, bahwa pengelolaan teknologi informasi yang dilakukan telah mencapai level Repeatable But Intuitive, yang artinya pada level ini, proses telah berkembang pada tahap dimana prosedur serupa diikuti oleh orang berbeda yang melakukan tugas yang sama. Tidak ada pelatihan dan komunikasi formal dari prosedur standar, dan tanggung jawab diserahkan kepada individu. Hasil penilaian terdapat pada Tabel 6. Hasil Perhitungan Maturity Level ME \& DS.. 
Tabel 6. Hasil perhitungan maturity level $M E \& D S$

\begin{tabular}{llc}
\hline Domain & Keterangan Domain & $\begin{array}{c}\text { Hasil } \\
\text { rata-rata }\end{array}$ \\
\hline ME1 & $\begin{array}{l}\text { Monitor and Valuate IT } \\
\text { Performance }\end{array}$ & 2.3 \\
\hline ME4 & $\begin{array}{l}\text { Provide IT Governance } \\
\text { DS5 }\end{array}$ & 2.14 \\
\hline DS8 & $\begin{array}{l}\text { Mansure Systems Security } \\
\text { and Incidents }\end{array}$ & 1.63 \\
\hline DS11 & Manage Data & 1.6 \\
\hline \multicolumn{2}{c}{ Rata-rata } \\
\hline
\end{tabular}

\section{Perhitungan Gap}

Setelah menilai dan mengetahui tingkat kematangan tata kelola saat ini sebesar 1.97, maka dilakukan analisis kesenjangan terhadap tingkat kematangan yang diharapkan, yaitu sebesar 3 . Analisa ini diharapkan dapat memberikan kemudahan bagi pengelolaan teknologi informasi yang selaras diantara ke-4 domain. Alasan nilai yang ingin dicapai sebesar 3 adalah melihat kesiapan kantor dalam bidang tata kelola manajemen, pengelolaan SDM dan Keuangan. Tabel 7. Hasil Perhitungan Gap Rata-rata di bawah ini, menunjukkan jarak (gap) antara tingkat kematangan saat ini dengan tingkat kematangan yang diharapkan. Terdapat Jarak 2 pada domain ME dan DS, antara kondisi yang diharapkan dengan kondisi saat ini. Nilai gap terbilang cukup besar, sehingga membutuhkan tingkat penyesuaian yang berbedabeda karena domain ME bernilai 0.8 sedangkan nilai domain DS adalah 1.2.

\begin{tabular}{|c|c|c|c|}
\hline \multirow[t]{2}{*}{ Domain } & \multicolumn{3}{|c|}{ Nilai Maturity Level } \\
\hline & $\begin{array}{l}\text { Saat } \\
\text { Ini }\end{array}$ & Diharapkan & Gap \\
\hline ME & 2.2 & 3 & $3-2.2=0.8$ \\
\hline \multirow[t]{2}{*}{ DS } & 1.8 & 3 & $3-1.8=1.2$ \\
\hline & & ta-rata & $0.8+1.2=2$ \\
\hline
\end{tabular}

\section{Perhitungan Gap Per Domain}

Masing-masing sub-domain yang digunakan sebagai bahan pertimbangan dalam peningkatan kerja proses pada masing-masing sub-domain, terutama pada proses bagian subdomain yang masih perlu di kembangkan. Expected level (diharapkan) ini ditetapkan untuk dapat mendukung kinerja tata kelola teknologi informasi pada PT. EMD, sehingga dapat berjalan dengan lebih baik dan efisien. Melihat hasil maturity level saat ini, maka peneliti menetapkan nilai 3 sebagai nilai expected level pada setiap domain dari ME1, ME4, DS5, DS8, dan DS11. Adapun nilai gap maturity level tersebut dapat dilihat pada Tabel 8 .

Tabel 8. Hasil perhitungan gap per domain

Tabel 8. Hasil Perhitungan Gap Per Domain

\begin{tabular}{cccc}
\hline \multirow{2}{*}{$\begin{array}{c}\text { Sub } \\
\text { Domain }\end{array}$} & \multicolumn{3}{c}{ Nilai Maturity Level } \\
\cline { 2 - 4 } & $\begin{array}{c}\text { Saat } \\
\text { Ini }\end{array}$ & $\begin{array}{c}\text { Diharap } \\
\text { kan }\end{array}$ & Gap \\
\hline ME1 & 2.3 & 3 & $3-2.3=0.7$ \\
\hline ME4 & 2.14 & 3 & $3-2.14=0.86$ \\
\hline DS5 & 1.63 & 3 & $3-1.63=1.37$ \\
\hline DS8 & 1.6 & 3 & $3-1.6=1.4$ \\
\hline DS11 & 2.17 & 3 & $3-2.17=0.83$ \\
\hline
\end{tabular}

\section{Grafik Maturity Level}

Sejauh ini PT. EMD sudah memiliki tata kelola teknologi informasi yang cukup baik. Berdasarkan hasil yang terdapat pada tabel-tabel sebelumnya, tata kelola teknologi informasi PT. EMD telah mencapai level Repeatable But Intuitive, sehingga PT. EMD hanya perlu memperbaiki dan meningkatkan kinerja pada domain-domain tersebut, seperti pada grafik yang ditunjukkan pada Gambar 3.

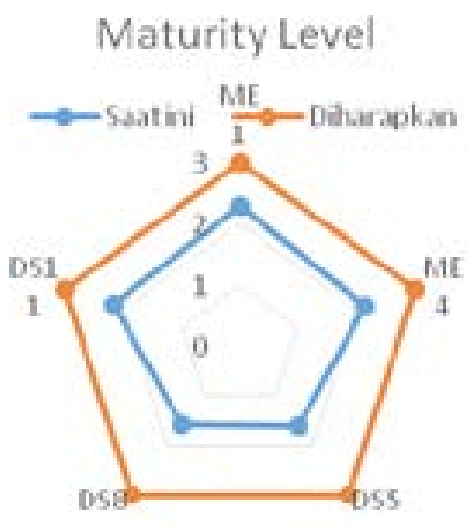

Gambar 3. Grafik maturity level

Keselarasan TI Terhadap Kinerja Perusahaan Dengan Perspektif Pelanggan dan Proses Internal 
Tabel 9. Keselarasan perspektif pelanggan

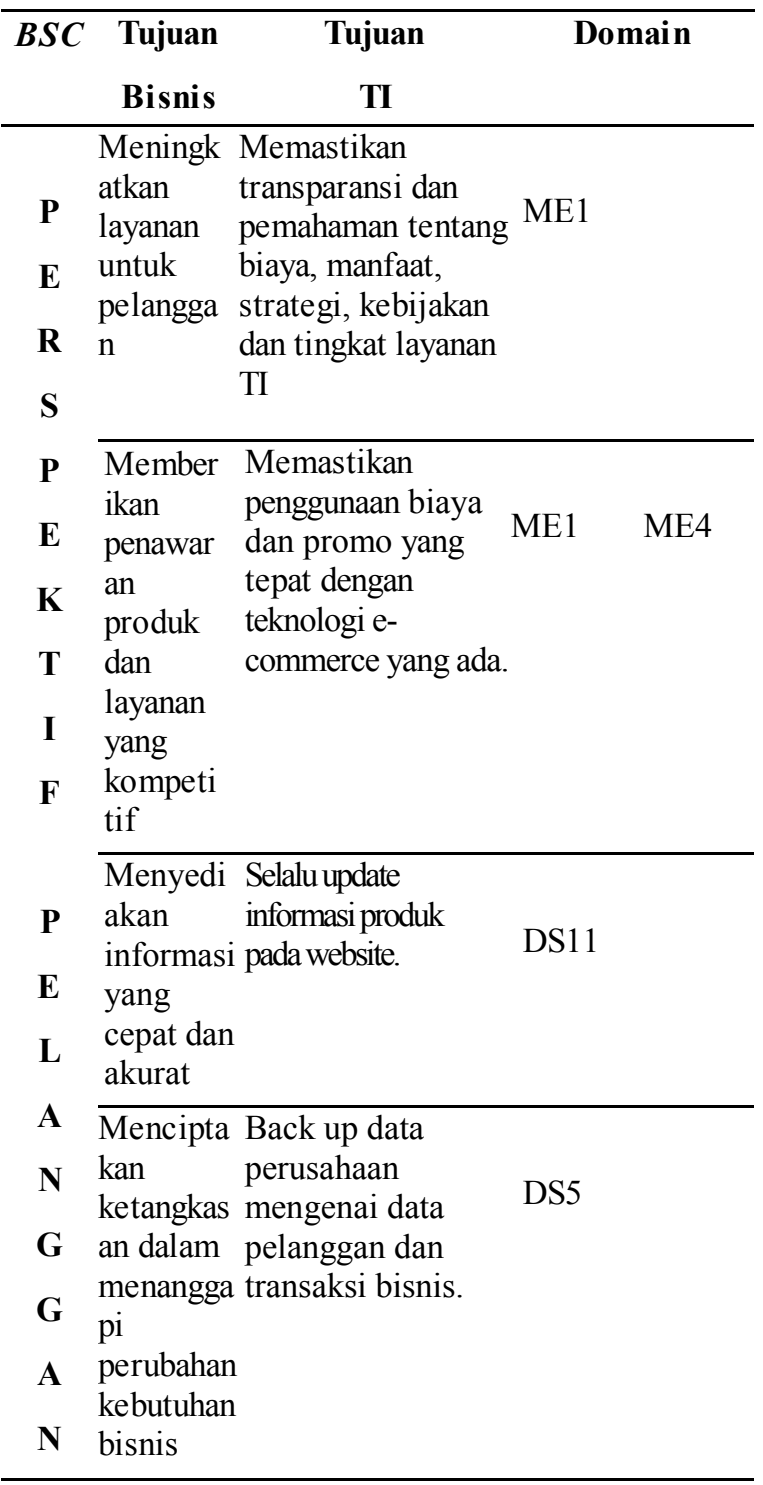

Pada Tabel 9. Keselarasan Perspektif Pelanggan, terdapat keselarasan TI terhadap kinerja perusahaan yang dijelaskan melalui tabel tujuan bisnis dan tujuan TI dan domain-domain yang telah di pilih berdasarkan COBIT 4.1 dengan perspekif yang di gunakan adalah perspektif pelanggan dan perspektif proses internal menggunakan Balanced Scorecard.

Dari perspektif pelanggan, tujuan bisnis yang pertama adalah meningkatkan layanan untuk pelanggan, terutama pelanggan lama sehingga bisa menarik perhatian pelanggan untuk tetap nyaman dalam berlangganan pada perusahaan. Tujuan bisnis yang kedua adalah memberikan penawaran dan layanan yang kompetitif, sehingga dapat bersaing dengan perusahaan sejenis yang bergerak di bidang yang sama. Tujuan bisnis yang ketiga adalah menyediakan informasi yang cepat dan akurat. Contohnya adalah informasi harga terupdate, promosi, produk new arrival, dan lain-lain. Dan tujuan bisnis mengenai pelanggan yang terakhir adalah menciptakan ketangkasan dalam menghadapi perubahan kebutuhan bisnis. Sehingga, perusahaan dapat mengikuti dan menyesuaikan diri dengan kebutuhan bisnis saat ini.

Tujuan TI mengenai pelanggan yang pertama adalah Memastikan transparansi dan pemahaman tentang biaya, manfaat, strategi, kebijakan dan tingkat layanan TI. Tujuan ini berkaitan dengan domain ME1 yang focus mengenai Monitoring and Evaluate IT Performance. Tujuan TI yang kedua adalah memastikan penggunaan biaya dan promo yang tepat dengan teknologi e-commerce yang ada. Tujuan ini berhubungan dengan domain ME1 yang berfokus pada Monitoring and Evaluate IT Performance pada perusahaan, dan ME4 yang focus mengenai IT Governance. Penjualan perusahaan melalui e-commerce tentu berhubungan dengan Performa TI dan tata kelolanya. Tujuan TI yang ketiga adalah selalu update informasi produk pada website. Hal ini dimaksudkan perusahaan untuk selalu follow up pelanggan. Tujuan ini berkaitan dengan domain DS11 mengenai Manage Data, agar perusahaan dapat mengelola informasi secara berkala. TI yang keempat adalah back up data perusahaan mengenai data pelanggan dan transaksi bisnis. Kebutuhan mengenai keamanan data ini berkaitan dengan domain DS5, yaitu mengenai Ensure System and Security, yang berbicara mengenai bagaimana memiliki, meningkatkan, dan memastikan keamanan pada system dan data perusahaan.

Pada Tabel 10. Keselarasan Perspektif Proses Internal, terdapat keselarasan TI terhadap kinerja perusahaan yang dijelaskan melalui tabel tujuan bisnis dan tujuan TI dan domain-domain yang telah di pilih berdasarkan COBIT 4.1 dengan perspekif yang di gunakan adalah perspektif pelanggan dan perspektif proses internal menggunakan Balanced Scorecard.

Dari perspektif proses internal, tujuan bisnis yang pertama adalah pemeliharaan proses bisnis. Maka yang harus dilakukan TI adalah mempermudah dan mempercepat secara akurat kebutuhan akan data. Data disini dimaksud sebagai data apapun yang pada saat tertentu dibutuhkan perusahaan. Contohnya adalah data mengenai pengarsipan, identifikasi resiko, dan lain sebagainya. Tujuan TI tersebut berkaitan dengan domain ME1 mengenai monitoring dan evaluasi performa TI, dan DS11 yang focus mengenai pengelolaan data. Kemudian tujuan TI yang kedua adalah memfasilitasi dalam mengotomatisasi kinerja bisnis perusahaan. Keberadaan tata kelola TI diharuskan mendukung dan mempermudah kinerja bisnis perusahaan. Tujuan ini berhubungan dengan domain ME4 mengenai tata kelola TI. 
Tabel 10 Keselarasan perspektif proses internal

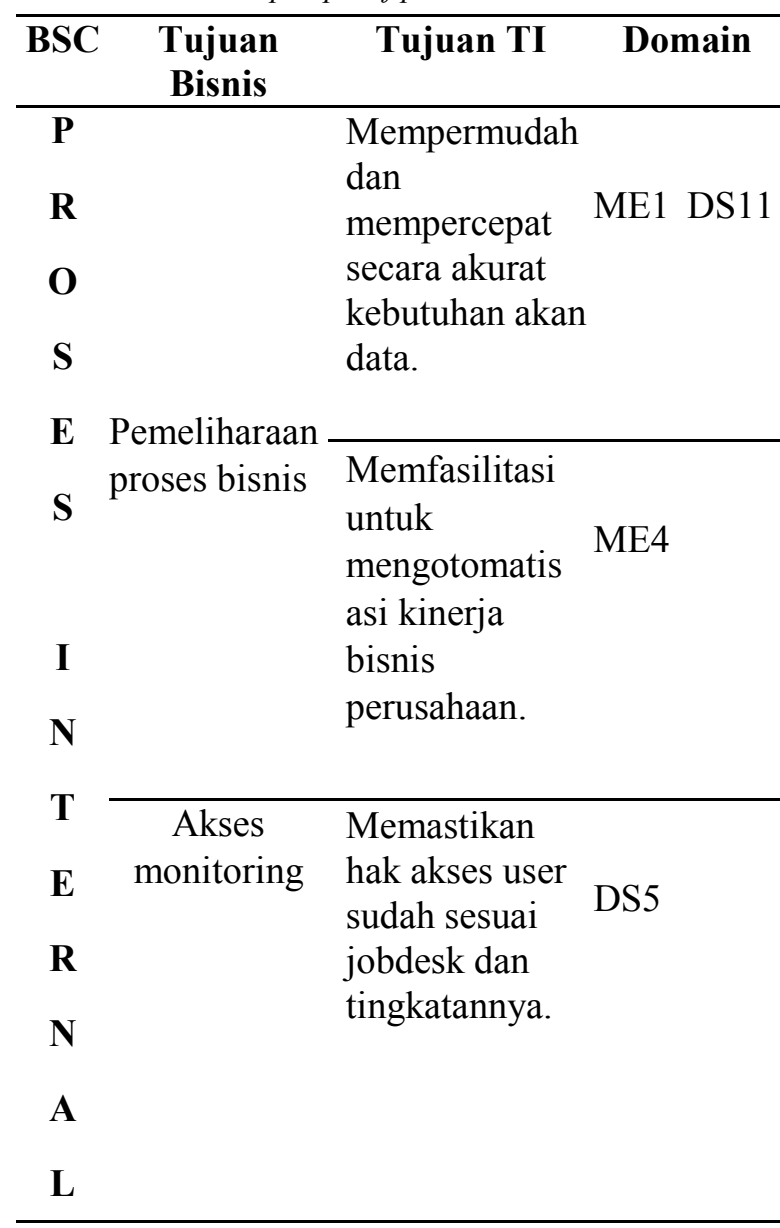

Tujuan bisnis yang kedua adalah akses monitoring. Ini dimaksudkan perusahaan agar mengurangi terjadinya kesalahan system yang memengaruhi proses bisnis. Maka tujuan TI adalah memastikan dan membatasi hak akses user agar sesuai dengan jobdesk dan tingkatan aksesnya. Tujuan ini berhubungan dengan domain DS5 mengenai keamanan system dan data perusahaan.

\section{SIMPULAN}

Berdasarkan hasil penelitian yang telah dilakukan, maka dapat ditarik kesimpulan sebagai berikut: 1) Perusahaan E Media Devices telah menerapkan tata kelola teknologi informasi dan mampu memperoleh level Repeatable But Intuitive. Hasil pengolahan wawancara dan observasi mendapati nilai rata-rata untuk domain ME dan DS adalah 2.0 dari rentang nilai 0 sampai 5 , sehingga diharapkan dengan rekomendasi dan temuan masalah yang didapat oleh peneliti dapat berguna untuk Perusahaan E Media Devices.

Berdasarkan hasil penelitian, ditemukan kelemahan pada DS8, DS5. Pada domain ini hanya mendapatkan nilai rata-rata 1.6 untuk DS8, dan 1.63 pada DS5 artinya masih pada level Repeatable
But Intuitive. Beberapa kelemahan yang ada pada DS8 dan DS5 adalah perusahaan tidak menerapkan Cryptographic Key Management dalam setiap transaksi yang digunakan yang artinya keamanan perusahaan masih dalam tahap yang harus diperbaiki. Prosedur dan kebijakan keamanan perusahaan belum di lakukan dengan sungguh-sungguh.

Pada persperktif pelanggan, tujuan bisnis perusahaan dengan tujuan TI sudah cukup berkaitan, kecuali pada tujuan yang terakhir, yaitu tujuan bisnis perusahaan adalah menciptakan ketangkasan dalam menanggapi perubahan kebutuhan bisnis, sedangkan tujuan TI adalah back up data perusahaan mengenai data pelanggan dan transaksi bisnis. Peneliti tidak menemukan adanya keselarasan mengenai tujuan tersebut.

Pada perspektif proses internal, sejauh ini perusahaan sudah memiliki proses internal yang cukup baik, karena tujuan bisnis dengan TI perusahaan sudah selaras.

\section{DAFTAR RUJUKAN}

[1] J. F. Andry \& B. Setiawan. Conceptual Framework for Successful IT Governance and BSC for Service Industry. hlm 1-6. 2018

[2] A. Anand., S. F. Wamba \& D. Gnanzou. A Literature Review on Business Process Management, Business Process Reengineering, and Business Process Innovation. Enterprise and Organizational Modeling and Simulation, Eomas, hlm 1-23. 2013

[3] N. O. Putri. "Evaluasi Tata Kelola IT pada PT Telkom Indonesia dengan Kerangka Kerja COBIT 4.1 Berdasarkan Perspektif Pelayanan Pelanggan Produk Telkom”. Jurusan Sistem Informatika, Fakultas Teknik dan Ilmu Komputer, Universitas Komputer Indonesia. hlm 75. 2013

[4] J. F. Andry. Performance Measurement of IT Governance: A Case Study. Jurnal Sistem Informasi, 12(2), hlm 57-63. 2016

[5] Wella \& J. Setiawan. Audit Sistem Informasi Menggunakan Cobit 4.1 pada PT. Erajaya Swamsebada, Tbk. ULTIMA InfoSys, VI. hlm 71. 2015

[6] S. Gondodiyoto. Audit Sistem Informasi + pendekatan COBIT Edisi Revisi, Mitra Wacana Media, Jakarta. hlm 37. 2007

[7] G. A. T. Krisanthi., I. M. Sukarsa \& I. P. Agung Bayupati. Governance audit of application procurement using COBIT framework. Journal of Theoretical and Applied Information Technology, 59(2), 342-351. 2014 
[8] IT Governance Institute Team. COBIT 4.1. USA: IT Governance Institute. 2007

[9] A. A. Latif and N. Hanifi, "Analyzing IT Function Using COBIT 4.1 - A Case Study of Malaysian Private University," Journal of Economics, Business and Management, Vol. 1, Issue, 4, 2013.

[10] R. A. Kisner. Using the Balanced Scorecard to Achieve Career Success. Government Finance Review, 23(5), 65-68. 2007

[11] O. Zizlavsky. The balanced scorecard: Innovative performance measurement and management control system. Journal of Technology Management and Innovation,9(3),210-222. https://doi.org/10.4067/ S0718-27242014000300016. 2014
[12] P. Brewer, "Putting Strategy into The Balanced Scorecard," Strategic Finance, Vol. 83, Issue. 7, 2002.

[13] A. Gumbus \& B. Lyron, "The Balanced Scorecard at Philips Electronics," Strategic Finance, Vol. 45, 2002.

[14] J. F. Andry and B. Sanjaya, "Audit Tata Kelola TI Pada PT. Porto Indonesia Sejahtera Menggunakan COBIT Pada Domain PO," Jurnal Ilmiah Teknologi Terapan, Vol.3, Issue. 30, 2017 